\title{
Evaluasi Program Bank Sampah Sibuh Nirmala Di Desa Kedisan Kecamatan Kintamani Kabupaten Bangli
}

\author{
I Wayan Dedi Ariawan \\ Program Studi Pendidikan Ekonomi, Fakultas Ekonomi, Universitas Pendidikan Ganesha \\ email: dediariawaniwayan11@gmail.com \\ Luh Indrayani \\ Program Studi Pendidikan Ekonomi, Fakultas Ekonomi, Universitas Pendidikan Ganesha \\ email: luhindrayani25@gmail.com
}

\section{Rudi Irwansyah}

Program Studi Pendidikan Ekonomi, Fakultas Ekonomi, Universitas Pendidikan Ganesha email: rudi.irwansyah@undiksha.ac.id

\begin{abstract}
Abstrak
Tujuan penelitian ini untuk mengetahui tingkat keberhasilan atau efektivitas program Bank Sampah Sibuh Nirmala di Desa Kedisan, diukur dari komponen konteks, input, proses dan produk. Penelitian ini termasuk dalam jenis penelitian studi evaluasi. Subjek dalam penelitian ini ialah nasabah Bank Sampah Sibuh Nirmala sejumlah 32 orang dan objek pada penelitian ini adalah program bank sampah. Metode yang digunakan untuk pengumpulan data berupa kuesioner dan dokumentasi. Teknik analisis data yang digunakan dalam penelitian ini adalah deskriptif kuantitatif dengan memakai rumus z-skor yang kemudian diubah ke dalam t-skor, setelah itu dikonversikan ke dalam kuadran prototype teori Glickman. Hasil penelitian menunjukkan bahwa, program Bank Sampah Sibuh Nirmala di Desa Kedisan tergolong cukup efektif karena CIPP berada pada posisi kuadran II prototype teori Glickman (+-++) yakni konteks bernilai positif, input bernilai negatif, proses bernilai positif, dan produk bernilai positif.
\end{abstract}

Kata kunci: Evaluasi, Model CIPP, Program Bank Sampah

\begin{abstract}
The main purpose of this research was to identify the success rate or effectiveness of Bank Sampah Sibuh Nirmala program at Kedisan Village, which was measured based on the context, input, process, and product components. This research was categorized into evaluasion research. The research subjects were 32 costumers of waste bank program and the research object was waste bank program itself. Data collection methods used were questionnaire and documentation. The data analysis technique was descriptive quantitative with the formula of $\mathrm{z}$-core further being changed into t-score, and the data was conversed into Glickman's prototype quadran theory. The research finding presented that the Bank Sampah Sibuh Nirmala program at Kedisan Village classified as effective enough because CIPP was in quadran II Glickman's prototype theory (+-++) whose context valued positive, input valued negative, process valued positive, and product valued positive.
\end{abstract}

Keyword: Evaluation, CIPP Model, Waste Bank Program

\section{PENDAHULUAN}

Permasalahan lingkungan merupakan permasalahan yang mengakibatkan rusaknya lingkungan sebagai tempat tinggal makhluk hidup. Hal tersebut sebagian besar berasal dari kegiatan sosial ekonomi manusia yang pada dasarnya untuk memenuhi kebutuhan hidupnya. Disisi lain, kegiatan tersebut menimbulkan dampak negatif yakni munculnya sampah (Kahfi, 2017). Menurut Hartono (2008) menyatakan sampah adalah material sisa yang sudah dibuang dan tidak dapat dipakai lagi apabila tidak diolah terlebih dahulu, yang berasal dari manusia, hewan, dan tumbuhan.
Keberadaan sampah bisa sangat mengkhawatirkan jika tidak segera ditangani dan dikelola dengan baik. Sampah juga dapat menjadi sumber timbulnya penyakit, disebabkan oleh timbunan sampah seperti pecahan logam dan plastik yang dapat menampung air ketika hujan sehingga menjadi sarang berkembang biak untuk nyamuk penyebab deman berdarah (Wardi, 2012). Timbulan sampah tidak akan berkurang atau habis karena akan terus bertambah sejajar dengan tingkat pertumbuhan penduduk yang semakin banyak, kompleksnya aktivitas yang dilakukan manusia, dan pola konsumsi masyarakat (Riswan, Sunoko, \& 
Hadiyanto, 2015). Timbulnya sampah yang semakin banyak setiap harinya menyebabkan berkurangnya ruang dan akan mengganggu kegiatan manusia, sehingga membuat kualitas hidup menjadi rendah dan tidak baik.

Sampah memang masalah yang sulit untuk diatasi oleh masyarakat, bisa dilihat dari banyaknya sampah yang berceceran di jalan atau disembarang tempat, bahkan disepanjang sungai banyak tercemar oleh sampah (Suryati, 2014). Bali yang dikenal sebagai tempat pariwisata yang indah juga dihadapkan dengan permasalahan dalam pengelolaan sampah. Berdasarkan data dari Kementerian Lingkungan Hidup dan Kehutanan Republik Indonesia (2018), banyaknya timbulan sampah di Bali pada periode 2017 sampai dengan 2018 mencapai $3.039,8$ ton per hari dengan kpmposisi sampah anorganik sebesar 39,78\% dan sisanya sampah organic. Sampah tersebut bersumber dari rumah tangga sebesar 53,51\%, pasar tradisional $13,27 \%$, plastik publik 4,59\%, sampah pusat perniagaan $4,11 \%$, dan dari perkantoran $3,48 \%$.

Permasalahan sampah di Bali terjadi hampir di semua kabupaten yang ada, salah satunya adalah Kabupaten Bangli yang diketahui menghasilkan timbulan sampah sebanyak 159,09 ton per hari. Tempat Pemrosesan Akhir (TPA) sampah di Kabupaten Bangli terletak di Desa Landih, Kecamatan Bangli. Seluruh sampah di bangli diangkut untuk di buang ke tempat ini, sehingga menyebabkan TPA cepat penuh. Hal tersebut juga diakibatkan oleh kurangnya peran aktif masyarakat dalam mendukung program pemerintah untuk menggulangi permasalahan sampah. Konsep penanganan sampah tidak hanya terletak pada keberadaan tempat pembuangan sampah, akan tetapi pada bagaimana sistem pengelolaan dan pengolahan yang dilaksanakan guna menurunkan volume sampah. Selama ini pengelolaan sampah hanya dilakukan secara sederhana yaitu dikumpulkan, diangkut, kemudian dibuang ke TPA. Oleh karena itu, menurut Peraturan Pemerintah Nomor 81 Tahun 2012 mengamanatkan perlu adanya transformasi paradigma yang mendasar untuk mengelola sampah yaitu dari pengumpulan, pengangkutan serta pembuangan menjadi pengelolaan yang fokus untuk mengurangi dan menangani sampah. Tindakan tersebut bertujuan agar seluruh pihak, baik para pelaku bisnis, instansi pemerintah serta masyarakat luas melakukan pengurangan timbulan sampah, pengolahan kembali atau pendauran ulang, dan pemanfaatan kembali sampah.

Program yang dilaksanakan dalam upaya pengurangan dan penanganan sampah di Kabupaten Bangli yaitu melalui program bank sampah. Sejalan dengan penyataan dari Peraturan Menteri Negara Lingkungan Hidup RI Nomor 13 Tahun 2012 menyatakan untuk mengatasi dan mengurangi timbulan sampah yakni dengan bank sampah. Menurut Prasetyo, Sakti, Gartika, Sukamsi, \& Arifin (2018) bank sampah merupakan suatu media yang dipakai oleh masyarakat guna menabung sampah dan dapat menjadi sumber untuk memperoleh pendapatan tambahan, serta secara tidak langsung membantu masyarakat dalam memilah sampah. Konsep dari bank sampah itu sendiri adalah dimana para penabung sampah harus memilah terlebih dahulu sampahnya yang akan ditabung. Program bank sampah selain dalam fungsinya untuk mengatur dan mengelola lingkungan agar tetap bersih, juga menjadi salah satu aspek penting dalam dalam konteks perekonomian masyarakat. Hal ini telah sejalan dengan hasil penelitian yang dilakukan Asteria \& Heruman (2016); Wulandari, Utomo, \& Narmaditya (2017) bahwa bank sampah membawa dampak yang baik terhadap perekonomian masyarakat sekitarnya melalui manajemen sampah menjadi halhal yang bernilai ekonomis secara swadaya.

Bank sampah sebagai tata kelola mengatasi masalah lingkungan berbasis masyarakat memiliki instrument untuk membangun kemandirian masyarakat, kemandirian yang dimaksud bukan hanya kemandirian dibidang ekonomi dan sosial, juga kemandirian di dalam aspek pendidikan serta teknologi. Pada aspek pendidikan, proses bank sampah yaitu pemilahan, pengumpulan, dan pelakasanaan daur ulang sampah secara tidak langsung meningkatkan pemahaman dan pengetahuan masyarakat untuk peduli dengan sampah serta diharapkan berdampak pada budaya yang pro-lingkungan. Pada aspek teknologi, karena dalam manajemennya berbasis masyarakat, mendorong bank sampah untuk melakukan inovasi agar pengelolaan sampah berjalan dengan efektif melalui kerjasama dengan koperasi atau instansi yang lain (Wijayanti \& Suryani, 2015).

Salah satu bank sampah yang sudah terbentuk di Kabupaten Bangli adalah Bank Sampah Sibuh Nirmala yang terletak di Desa Kedisan, Kecamatan Kintamani. Bank sampah ini dikomandani oleh I Gede Putrayasa Tangkas 
dengan jumlah nasabah sebanyak 32 orang. Dengan adanya bank sampah ini diharapkan dapat menanggulangi masalah sampah yang ada di lingkungan Desa Kedisan terutama di sekitaran Danau Batur. Namun, seiring berjalannya waktu jumlah nasabah di bank sampah ini tidak mengalami peningkatakan (tidak berkembang), telebih lagi hanya sebanyak 15 orang yang masih secara rutin menabung. Selain itu, jumlah tabungan di bank sampah ini juga mengalami penurunan. Pada awal berjalannya bank ini antusias nasabah sangat baik, hal itu terbukti dari jumlah tabungan sampah yang mampu dikumpulkan, yaitu sampah organic mencapai $250 \mathrm{~kg}$ dalam 1 bulan dan sampah plastic mencapai $300 \mathrm{~kg}$ dalam 2 bulan. Akan tetapi kenyataan pada saat ini, jumlah tabungan sampah organik dalam 1 bulannya hanya mencapai $150 \mathrm{~kg}$ dan sampah plastik $130 \mathrm{~kg}$ dalam 2 bulan. Salah satunya penyebabnya adalah kurangnya pemahaman dan pengetahuan masyarakat akan pentingnya pengelolaan sampah guna mengatasi masalah sampah. Shentika (2016) juga mengindikasikan bahwa banyak masyarakat yang tidak bergabung menjadi nasabah di bank sampah diakibatkan oleh rendahnya kesadaran dan partisipasi masyarakat. Padahal masyarakat yang tinggal di Desa Kedisan bisa memanfaatkan sampah yang ada di lingkungan sekitarnya terutama di rumah, danau dan dermaga untuk memperolah pendapatan tambahan.

Melihat permasalahan di atas, maka perlu dilaksanakan evaluasi terhadap program Bank Sampah Sibuh Nirmala tersebut. Rizani (2019) menyatakan bahwa evaluasi merupakan hasil kebijakan yang pada kenyataanya mempunyai nilai dari hasil tujuan atau sasaran kebijakan. Bank Sampah Sibuh Nirmala perlu dievaluasi yaitu untuk mengetahui efektif atau tidaknya program tersebut di Desa Kedisan. Sejalan dengan pendapat Arifin (2019) bahwa evaluasi terhadap suatu program dilakukan dengan tujuan untuk mengetahui efektivitas dan efesiensi suatu program, untuk mengetahui ketercapaian tujuan yang telah ditetapkan, untuk mengetahui relevansi pelaksanaan program dengan rencana program, untuk mengetahui dampak yang ditimbulkan setelah program dijalankan, untuk melihat kekuatan dan kelemahan program, dan menyediakan informasi untuk membuat keputusan terhadap program. Evaluasi program bank sampah tersebut dapat dilakukan dengan model evaluasi CIPP (Context, Input, Porcess, and Product), karena model evaluasi ini paling banyak dikenal dan digunakan untuk evaluasi sebuah program serta dapat berorientasi membantu administrator di dalam membuat keputusan (Arifin, 2019). Sejalan dengan hal tersebut Arikunto \& Jabar (2009) menyatakan model evaluasi CIPP sangat tepat dan akurat dipakai untuk mengevaluasi sebuah program karena model ini mengukur objek sasaran evaluasinya secara menyeluruh yaitu mulai dari konteks, input atau masukan, proses sampai dengan hasil. (Ridha, Sri, \& Ayu, 2018) juga menyatakan model ini dalam pelaksanaanya lebih banyak dipakai oleh evaluator karena lebih konprehensif dibandingkan dengan model yang lain.

Berdasarkan paparan masalah di atas, maka penulis tertarik untuk melakukan penelitian dengan mengevaluasi program bank sampah tersebut. Tujuan dilakukannya penelitian ini guna mengetahui tingkat efektivitas program Bank Sampah Sibuh Nirmala ditinjau dari komponen konteks, input, proses, dan produk.

\section{METODE}

Penelitian ini adalah jenis penelitian studi evaluatif yang bertujuan guna mengukur efektivitas atau keberhasilan sebuah program. Penelitian ini mengevaluasi program Bank Sampah Sibuh Nirmala di Desa Kedisan, evaluasi dilakukan dengan menggunakan model CIPP yang memfokuskan evaluasi terhadap komponen konteks, input, proses, dan produk. Pada penelitian ini yang menjadi subjek penelitian ialah nasabah Bank Sampah Sibuh Nirmala yang berjumlah 32 orang dan subjek penelitian ini adalah program bank sampah.

Penelitian ini memakai dua sumber data yaitu pertama data primer berupa skor yang diperoleh dari kuesioner yang dijawab oleh responden terkait evaluasi program bank sampah, dan data sekunder yakni berupa asip yang berisi nama-nama nasabah Bank Sampah Sibuh Nirmala. Jenis data yang dipakai pada penelitian ini adalah data kuantitatif.

Metode pengumpulan data pada penelitian ini adalah kuesioner dan dokumentasi. Kuesioner dipakai untuk memperoleh informasi terkait evaluasi program bank sampah. Dokumentasi digunakan untuk memperoleh arsip berupa namanama nasabah. Kuesioner dalam penelitian ini dinilai denga skala likert dari rentangan 1 sampai dengan rentangan 5. Jawaban dari responden Sangat 
Setuju (SS) diberikan skor 5, jawaban Setuju (S) diberikan skor 4, Kurang Setuju (KS) diberikan skor 3, Tidak Setuju (TS) diberikan skor 2, dan jawaban Sangat Tidak Setuju (STS) diberikan skor 1. Sebelum instrumen penelitian yang berupa kuesioner disebarkan kepada responden, terlebih dahulu harus dilakukan pengujian intrumen yakni uji validitas dan reliabilitas dengan tujuan mengetahui apakah pernyataan tiap kuesioner sudah tepat digunakan dalam penelitian di lapangan. Proses untuk melakukan pengujian validitas dan reliablitas pada penelitian ini dibantu menggunakan program Statistic Product and Service Solution (SPSS) for Window versi 20.

Data yang sudah diperoleh dari komponen konteks, input, proses, dan produk dianalisis secara kuantitatif dengan memakai analisis deskriptif. Pada studi evaluasi program ini data dianalisis dengan menggunakan skor standar atau z-skor yang selanjutnya diubah ke dalam bentuk t-skor, karena analisis dengan z-skor akan menghasilkan angkaangka yang tidak bulat dan tanda positif atau negatif, sehingga untuk mempermudah hasil perhitungan z-skor diubah ke t-skor agar memperoleh angka yang bulat.

Sesudah data diproses kemudian akan dianalisis secara deskriptif yang dibantu dengan menggunakan soffwer aplikasi Microsoft Excel For Window. Dalam menentukan tingkat keefektifan pelaksanaan program, dilakukan analisis terhadap komponen konteks, input, proses, dan produk melalui analisis kuadran prototype Glickman dengan menentukan kecenderungan arah z-skor yang telah diubah ke dalam t-skor bernilai positif atau negatif. Kententuanya yaitu jika $\mathrm{T} \geq 50$ berarti bernilai positif atau tinggi $(+)$ dan jika $\mathrm{T}<50$ berarti bernilai negatif atau rendah (-), untuk mengetahui hasil akhir dari masing-masing komponen dihitung dengan menjumlahkan skor positif dan skor negatifnya. Jika jumlah skor positif yang diperoleh lebih banyak atau sama dengan jumlah skor negatifnya maka hasil akhirnya positif ( skor $(+) \geq \sum$ skor $(-)=$ positif $)$, begitu juga sebaliknya jika jumlah skor positifnya lebih kecil dari pada jumlah negatifnya, maka hasilnya negatif $\left(\sum\right.$ skor $(+)<\sum$ skor $(-)=$ negatif $)$.

\section{HASIL DAN PEMBAHASAN}

\section{Hasil Penelitian}

Evaluasi Program Bank Sampah Sibuh Nirmala untuk komponen context diukur menggunakan empat indikator yaitu kebijakan terkait dengan program bank sampah, tujuan program, kebutuhan, dan harapan. Berikut disajikan hasil perhitungan pada setiap indikator komponen context setelah data mentah setiap indikator diubah ke dalam t-skor.

Tabel 1. Rekapitulasi Hasil Analisis Komponen Context pada Setiap Indikator.

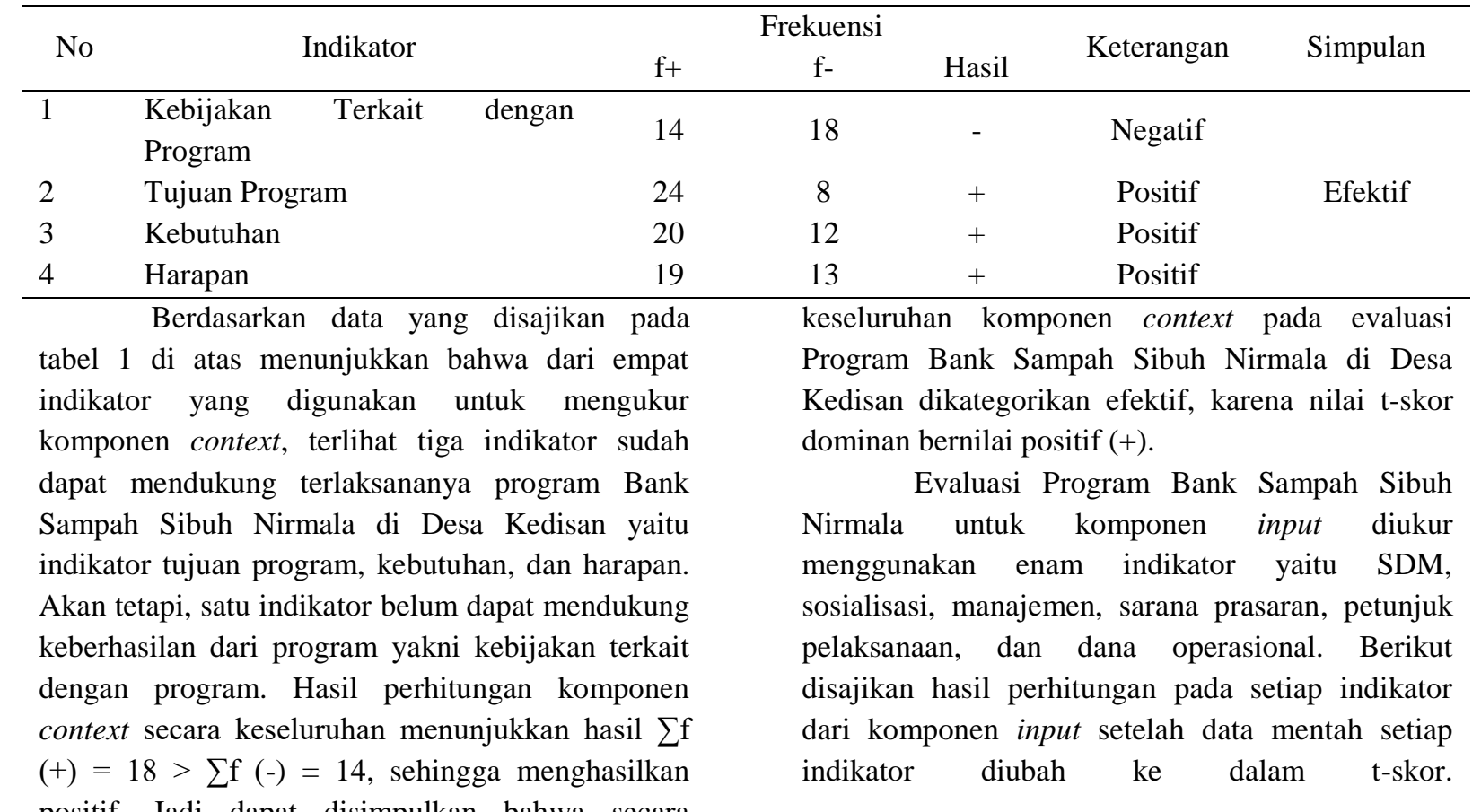


Tabel 2. Rekapitulasi Hasil Analisis Komponen Input pada Setiap Indikator.

\begin{tabular}{|c|c|c|c|c|c|c|}
\hline \multirow{2}{*}{ No } & \multirow{2}{*}{ Indikator } & \multicolumn{3}{|c|}{ Frekuensi } & \multirow{2}{*}{ Keterangan } & \multirow{2}{*}{ Simpulan } \\
\hline & & $\mathrm{f}+$ & $f-$ & Hasil & & \\
\hline 1 & SDM & 18 & 14 & + & Positif & \\
\hline 2 & Sosialisasi & 11 & 21 & - & Negatif & \\
\hline 3 & Manajemen & 22 & 10 & + & Positif & Kurang \\
\hline 4 & Sarana Prasaran & 12 & 20 & - & Negatif & Efektif \\
\hline 5 & Petunjuk Pelaksanaan & 8 & 24 & - & Negatif & \\
\hline 6 & Dana Operasional & 15 & 17 & - & Negatif & \\
\hline
\end{tabular}

Berdasarkan data yang disajikan pada tabel

2 di atas menunjukkan bahwa dari enam indikator yang digunakan untuk mengukur komponen input, terlihat dua indikator sudah dapat mendukung keberlangsungan program Bank Sampah Sibuh Nirmala di Desa Kedisan yaitu indictor SDM dan manajemen. Akan tetapi, empat indikator belum dapat mendukung keberhasilan dari program bank sampah yaitu sosialisasi, sarana prasarana, petunjuk pelaksanaan, dan dana operasional. Hasil perhitungan komponen input secara keseluruhan menunjukkan hasil $\sum \mathrm{f}(+)=15<\sum \mathrm{f}(-)=17$, sehingga menghasilkan negatif. Jadi dapat

Tabel 3. Rekapitulasi Hasil Analisis Komponen Process pada Setiap Indikator

\begin{tabular}{|c|c|c|c|c|c|}
\hline \multirow{2}{*}{ No } & \multirow{2}{*}{ Indikator } & \multicolumn{2}{|c|}{ Frekuensi } & \multirow{2}{*}{ Keterangan } & \multirow{2}{*}{ Simpulan } \\
\hline & & f- & Hasil & & \\
\hline 1 & Perencanaan Program & 15 & + & Positif & \multirow{4}{*}{ Efektif } \\
\hline 2 & Penyaluran Dana & 13 & + & Positif & \\
\hline 3 & Pemanfaatan Dana & 12 & + & Positif & \\
\hline 4 & Monitoring & 18 & - & Negatif & \\
\hline \multicolumn{2}{|c|}{ Berdasarkan data yang disajikan pada } & \multicolumn{4}{|c|}{ komponen process yang telah diukur pada evaluasi } \\
\hline \multirow{3}{*}{\multicolumn{2}{|c|}{$\begin{array}{l}\text { tabel } 3 \text { di atas memperlihatkan bahwa dari empat } \\
\text { indikator yang digunakan untuk mengukur } \\
\text { komponen process, terlihat tiga indikator sudah } \\
\text { dapat mendukung berlangsungnya Program Bank }\end{array}$}} & \multirow{2}{*}{\multicolumn{4}{|c|}{$\begin{array}{l}\text { Program Bank Sampah Sibuh Nirmala di Desa } \\
\text { Kedisan dikategorikan efektif, karena nilai t-skor } \\
\text { dominan memiliki nilai positif }(+) \text {. }\end{array}$}} \\
\hline & & & & & \\
\hline & & \multirow{7}{*}{\multicolumn{4}{|c|}{$\begin{array}{l}\text { Evaluasi Program Bank Sampah Sibuh } \\
\text { Nirmala untuk komponen product diukur dengan } \\
\text { menggunakan dua indikator yakni bank sampah } \\
\text { dapat mengurangi timbulan sampah dan bank } \\
\text { sampah dapat mengubah sampah agar memiliki } \\
\text { nilai ekonomis. Berikut disajikan hasil perhitungan } \\
\text { pada setiap indikator dari komponen product } \\
\text { setelah data mentah diubah ke dalam t-skor. }\end{array}$}} \\
\hline \multicolumn{2}{|c|}{$\begin{array}{l}\text { Sampah Sibuh Nirmala di Desa Kedisan yaitu } \\
\text { indikator perencanaan program, penyaluran dana, }\end{array}$} & & & & \\
\hline \multirow{5}{*}{\multicolumn{2}{|c|}{$\begin{array}{l}\text { dan pemanfaatan dana. Akan tetapi, satu indikator } \\
\text { belum dapat mendukung keberhasilan program } \\
\text { bank sampah yakni monitoring. Dari hasil } \\
\text { perhitungan komponen process secara keseluruhan } \\
\text { memperlihatkan hasil } \sum \mathrm{f}(+)=21>\sum \mathrm{f}(-)=11 \text {, } \\
\text { sehingga hasilnya positif. Jadi secara keseluruhan }\end{array}$}} & & & & \\
\hline & & & & & \\
\hline & & & & & \\
\hline & & & & & \\
\hline & & & & & \\
\hline \multicolumn{6}{|c|}{ Tabel 4. Rekapitulasi Hasil Analisi } \\
\hline \multirow{2}{*}{ No } & \multirow{2}{*}{ Indikator } & \multicolumn{2}{|c|}{ Frekuensi } & \multirow{2}{*}{ Keterangan } & \multirow{2}{*}{ Simpulan } \\
\hline & & f- & Hasil & & \\
\hline 1 & $\begin{array}{l}\text { Bank Sampah dapat Mengurangi } \\
\text { Timbulan Sampah }\end{array}$ & 7 & + & Positif & \multirow{4}{*}{ Efektif } \\
\hline \multirow{3}{*}{2} & Bank Sampah dapat Mengubah & & & & \\
\hline & Sampah Agar Memiliki Nilai & 11 & + & Positif & \\
\hline & & & & & \\
\hline
\end{tabular}
input pada evaluasi program Bank Sampah Sibuh Nirmala di Desa Kedisan dikategorikan kurang efektif, karena nilai dari t-skor dominan bernilai negatif (-).

Evaluasi Program Bank Sampah Sibuh Nirmala untuk komponen process diukur menggunakan empat indikator yaitu perencanaan program, penyaluruan dana, dan monitoring. Berikut disajikan hasil perhitungan pada setiap indikator dari komponen process setelah data mentah setiap indikator diubah ke dalam t-skor. 
Berdasarkan pada tabel 4, memperlihatkan bahwa dari dua indikator yang digunakan mengukur komponen product, terlihat bahwa kedua indikator tersebut sudah dapat mendukung keberhasilan program Bank Sampah Sibuh Nirmala di Desa Kedisan. Hasil perhitungan komponen product secara keseluruhan menunjukkan hasil $\sum \mathrm{f}(+)=19$ $>\sum \mathrm{f}(-)=13$, sehingga hasilnya positif. Jadi secara keseluruhan komponen product yang telah diukur untuk evaluasi program Bank Sampah Sibuh Nirmala di Desa Kedisan dikategorikan efektif, karena nilai t-skor dominan bernilai positif (+).

Tabel 5. Hasil Analisis Komponen Context, Input, Process, dan Product secara Keseluruhan

\begin{tabular}{llccccc}
\hline \multirow{2}{*}{ No } & \multirow{2}{*}{ Komponen } & $\mathrm{f}+$ & $\begin{array}{c}\text { Frekuensi } \\
\mathrm{f}-\end{array}$ & Hasil & Keterangan & \multirow{2}{*}{ Simpulan } \\
& & 18 & 14 & + & Positif & \\
\hline 1 & Context & 15 & 17 & - & Negatif & Cukup \\
2 & Input & 21 & 11 & + & Positif & Efektif \\
3 & Process & 19 & 13 & + & Positif & \\
4 & Product & 19 & & \\
\hline
\end{tabular}

Berdasarkan pada tabel 5 yang disajikan, dapat dilihat bahwa pada hasil perhitungan masingmasing komponen yang diukur, untuk komponen context memperoleh hasil $\sum \mathrm{f}(+)=18>\sum \mathrm{f}(-)=14$ yang menghasilkan positif, hal ini disebabkan karena dari empat indikator yang diukur sebagian indikator bernilai positif atau telah mendukung berjalannya program Bank Sampah Sibuh Nirmala. Komponen input menunjukkan hasil $\sum \mathrm{f}(+)=15<$ $\sum \mathrm{f}(-)=17$ yang menghasilkan negatif (kurang efektif), karena dari enam indikator yang diukur sebagian besar menghasilkan nilai negatif yang artinya belum mendukung keberhasilan program bank sampah. Komponen process menunjukkan hasil yakni $\sum \mathrm{f}(+)=21>\sum \mathrm{f}(-)=11$ yang berarti positif, karena dari empat indikator komponen process yang diukur sebagian besar telah mendukung terlaksananya program bank sampah. Dan untuk komponen product menunjukkan hasil $\sum \mathrm{f}(+)=19>\sum \mathrm{f}(-)=13$ yang berarti positif, karena semua indikator dari komponen product sudah mendukung berlangsungnya program Bank Sampah Sibuh Nirmala di Desa Kedisan. Secara keseluruhan dapat disimpulkan bahwa bahwa komponen context, input, process, dan product menghasilkan (+-++). Selanjutnya, untuk menentukan kefektifan program Bank Sampah Sibuh Nirmala di Desa Kedisan, data yang diperoleh pada tabel 5 di atas dapat dianalisis dengan mengaplikasikan ke dalam kuadran prototype teori Glickman sebagai berikut.

Tabel 6. Kuadran Prototype Diadopsi dari Teori Glickman

\begin{tabular}{|c|c|c|c|c|c|}
\hline \multicolumn{2}{|c|}{ Kuadran II } & \multicolumn{4}{|c|}{ Kuadran I } \\
\hline $\mathrm{C}$ & $\mathrm{P}$ & $\mathrm{C}$ & I & $\mathrm{P}$ & $\mathrm{P}$ \\
\hline+ & - & + & + & + & + \\
\hline+ & + & & & & \\
\hline+ & + & & & & \\
\hline- & + & & & & \\
\hline \multicolumn{2}{|c|}{ Cukup Efektif } & \multicolumn{4}{|c|}{ Efektif } \\
\hline \multicolumn{2}{|c|}{ Kuadran IV } & \multicolumn{4}{|c|}{ Kuadran III } \\
\hline $\mathrm{C}$ & $\mathrm{P}$ & $\mathrm{C}$ & I & $\mathrm{P}$ & $\mathrm{P}$ \\
\hline- & - & + & + & - & - \\
\hline & & + & - & - & + \\
\hline & & - & - & + & + \\
\hline & & - & + & + & - \\
\hline & & + & - & - & - \\
\hline & & - & + & - & - \\
\hline & & - & - & + & - \\
\hline \multicolumn{2}{|c|}{ Tidak Efektif } & \multicolumn{4}{|c|}{ Kurang Efektif } \\
\hline
\end{tabular}

Sumber: (Sahertian, 2006) 
Jadi berdasarkan hasil perhitungan masing-masing komponen pada tabel 5 sebelumnya, setelah hasil tersebut dikonversikan ke dalam kuadran prototype dari teori Glickman di atas, maka hasil evaluasi Program Bank Sampah Sibuh Nirmala di Desa Kedisan dinyatakan terletak pada kuadran II prototype teori Glickman yang berarti bahwa program bank sampah tersebut dikategorikan cukup efektif.

\section{Pembahasan}

Berdasarkan hasil penelitian yang diperoleh mengenai evaluasi program Bank Sampah Sibuh Nirmala di Desa Kedisan menunjukkan hasil bahwa program tersebut dikategorikan cukup efektif. Dapat dilihat pada masing-masing komponen yaitu pertama, hasil penelitian komponen context secara umum tergolong efektif, karena indikator tujuan program, kebutuhan, dan harapan sudah dapat mendukung berjalannya program Bank Sampah Sibuh Nirmala. Mulia, Rizka, \& Herlina (2016) juga mengindikasikan dalam hasil penelitiannya bahwa komponen context dikategorikan efektif karena program yang diselenggarakan sesuai dengan kebutuhan dan harapan dari masyarakat. Satu indikator yang belum dapat mendukung keberhasilan program bank sampah dalam penelitian ini adalah indikator kebijakan terkait dengan program. Pemerintah desa memang sudah mengeluarkan SK untuk Bank Sampah Sibuh Nirmala sebagai dasar hukum. Akan tetapi, peraturan terkait program bank sampah dari pemerintah desa juga diperlukan untuk mendukung keberhasilan program, seperti peraturan dilarangnya pemulung masuk desa.

Fakta dari hasil temuan di lapangan, tidak adanya peraturan dari pemerintah desa terkait program bank sampah berdampak pada banykanya masyarakat yang tidak memanfaatkan program bank sampah yang ada. Hal itu disebabkan karena masyarakat lebih dominan memilih menukarkan sampahnya pemulung. Oleh karena itu, seharusnya pemerintah desa membuat peraturan bahwa dilarangnya pemulung masuk desa agar Bank Sampah Sibuh Nirmala dimanfaatkan oleh masyarakat, sehingga dapat mendukung keberhasilan program dalam melakukan pengelolaan sampah secara mandiri.

Pada komponen input, hasil penelitian yang dilakukan menunjukkan secara umum bahwa komponen input dikategorikan kurang efektif. Sejalan dengan hasil penelitian Maulana, Supriyono, \& Hermawan (2013) dikatakan input tergolong kurang efektif disebabkan fasilitas yang dimiliki program masih belum memadai. Namun, dalam penelitian ini komponen input dikatakan kurang efektif karena dari enam indikator yang diukur, empat indikator belum dapat mendukung berlangsungnya Program Bank Sampah Sibuh Nirmala di Desa Kedisan yaitu indikator sosialisasi, sarana prasaran, petunjuk pelaksanaan, dan dana operasional. Dua indikator yang sudah mendukung berlangsungnya program tersebut yaitu SDM dan manajemen.

Indikator sosialisasi tidak dapat mendukung berlangsungnya program Bank Sampah Sibuh Nirmala, karena dari awal berjalannya program bank sampah tersebut hingga sekarang belum melaksanakan sosialisasi. Hal inilah yang menyebabkan banyak masyarakat yang tidak tahu dan mengerti tentang bank sampah itu sendiri. Sosialisasi sangat penting dilaksanakan untuk mengenalkan dan memberikan pemahaman kepada masyarakat terhadap program yang akan dijalankan (Triana \& Sembiring, 2018). Sehingga tidak bisa dipungkiri bahwa masalah banyaknya masyarakat yang tidak bergabung menjadi nasabah di bank sampah disebabkan karena tidak ada sosialisasi yang dilakukan oleh penyelenggara atau pelaksana program bank sampah.

Indikator petunjuk pelaksanaan juga tidak mendukung berlangsunya program Bank Sampah Sibuh Nirmala dikarenakan tidak ada petunjuk pelaksanaan yang dibuat oleh pengelola bank sampah. Hal itu menyebabkan tidak semua pihak memahami bagaimana pelaksanaan dari pengelolaan sampah yang dilakukan. Penyelenggara atau pengelola program bank sampah seharusnya melaksanakan sosialisasi dan membuat petunjuk pelaksanaan program agar masyarakat mengetahui dan memahami program bank sampah berserta pelaksanaan pengelolaan sampah yang dilakukan. Selain itu, indikator sarana prasaran dan dana operasional juga belum mendukung keberhasilan program, karena Bank Sampah Sibuh Nirmala tidak memiliki kendaraan pengangkut sampah untuk mengambil sampah-sampah yang sudah dipilah oleh nasabah. Dimana untuk saat ini, masyarakat yang menjadi nasabah lebih banyak rumahnya jauh dengan bank sampah, sehingga membuat nasabah jarang untuk menabungkan sampahnya, dan lebih memilih untuk menukarkan sampahnya kepada pemulung karena dianggap lebih mudah dan praktis. Bantuna dana yang diberikan oleh pemerintah desa juga tidak cukup untuk membeli kendaraan pengakut sampah, dikarenakan bantuan dana yang diberikan sebesar Rp.65.000.000,00 sudah dialokasikan untuk membangun gudang sebesar Rp.35.000.000,00 dan Rp.30.000.000,00 digunakan untuk membeli peralatan dan perlengkapan penunjang pelaksanaan program bank sampah. Maka dari itu, diperlukan bantuan berupa kendaraan pengangkut sampah dari pemerintah agar pelaksanaan program bank dapat berjalan dengan maksimal.

Pada komponen process, hasil penelitian yang dilaksanakan memperlihatkan bahwa secara keseluruhan komponen process dari program Bank Sampah Sibuh Nirmala dikategorikan efektif, sesuai dengan pernyataan 
Erilantu (2016) bahwa komponen process dikatakan tegolong efektif karena perencanaan dari program sudah berjalan dengan baik. Hasil penelitian penulis, dari empat indikator yang diukur, tiga indikator sudah dapat mendukung berjalannya program bank sampah yaitu perencanaan program, penyaluran dana, dan pemanfataan dana. Satu indikator yang belum dapat mendukung kebehasilan program adalah monitoring, karena pengawasan dan evaluasi oleh pemerintah desa terkait bantuan dana program bank sampah yang diberikan belum dilaksanakan sepanjang pelaksanaan program. Padahal monitoring memiliki peranan yang sangat penting untuk mendukung keberhasilan program. Adanya monitoring dan evaluasi yang dilaksanakan terkait bantuan program bank sampah sebenarnya akan membantu pemerintah desa mengetahui pencapaian hasil, kemajuan, kendala, dan sudah sejauhmana bantuan program bank sampah terlaksana dengan baik (Refita, Siregar, \& Suroso, 2017), sehingga memudahkan pemerintah desa membuat kebijakan terkait program bank sampah tersebut. Oleh karena itu, pemerintah desa seharusnya melaksanaan pengawasan secara rutin agar tujuan dibuatnya program dapat tercapai dengan baik.

Pada komponen product, hasil penelitian yang dilaksanakan memperlihatkan bahwa secara keseluruhan komponen product dikategorikan efektif. Dapat dilihat dari dua indikator yang digunakan untuk mengukur keefektifan atau keberhasilan program bank sampah mengasilkan nilai positif, dimana setelah adanya program Bank Sampah Sibuh Nirmala di Desa Kedisan berdampak pada berkurangnya sampah yang berceceran di jalan, berkurangnya timbulan sampah, dan sampah dapat diubah agar memiliki nilai ekonomis. Wulandari et al (2017); Saputro, Kismartini, \& Syafrudin (2015) juga menyatakan bahwa bank sampah bermanfaat untuk menjaga lingkungan agar tetap bersih serta berdampak pada ekonomi masyarakat lokal yang menabung di bank sampah. Selain dari pada itu, didukung juga dengan kegiatan rutin yang diselenggarakan Bank Sampah Sibuh Nirmala yaitu melaksanakan pembersihan satu bulan sekali di danau, lingkungan Desa Kedisan, dan pura-pura yang ada di Desa Kedisan, sehingga kebersihan lingkungan tetap terjaga.

Hasil penelitian ini sesuai dengan pendapat dari Arifin (2019) bahwa evaluasi program dilaksanakan dengan tujuan untuk melihat efektif atau tidaknya program yang dijalankan. Untuk mengetahui keefektifan program, data yang telah diperoleh dianalisis dengan mengaplikasikan ke dalam kuadran prototype yang diadopsi dari teori Glickman. Hasil evaluasi sebuah program dikategorikan cukuf efektif apabila terletak pada kuadran II prototype teori Glickman atau salah satu komponen memperlihatkan hasil negatif.

\section{SIMPULAN DAN SARAN}

\section{Simpulan}

Berdasarkan pada hasil penelitian dan pembahasan yang telah dipaparkan sebelumnya, maka dapat peneliti disimpulkan yaitu pertama, evaluasi program Bank Sampah Sibuh Nirmala di Desa Kedisan yang diukur dari komponen context dikategorikan efektif. Kedua, evaluasi program Bank Sampah Sibuh Nirmala di Desa Kedisan dilihat dari komponen input dikategorikan kurang efektif. Ketiga, evaluasi program Bank Sampah Sibuh Nirmala di Desa Kedisan yang diukur dari komponen process dikategorikan efektif. Keempat, evaluasi program Bank Sampah Sibuh Nirmala di Desa Kedisan yang diukur dari komponen product dikategorikan efektif.

\section{Saran}

Berdasarkan pada hasil evaluasi terhadap program bank sampah, dapat peneliti ajukan saran yaitu pertama, bagi pengelola Bank Sampah Sibuh Nirmala disarankan untuk melaksanakan sosialisasi agar seluruh masyarakat mengetahui dan mengerti terhadap program bank sampah yang dijalankan. Kedua, bagi pemerintah desa disarankan agar membuat peraturan terkait dilarangnya pemulung masuk desa sebagai bentuk dukungan keberhasilan program bank sampah dalam melaksanakan pengelolaan sampah secara mandiri. Pemerintah desa juga disarakan untuk melaksanakan monitoring sepanjang pelaksanaan program, agar mengetahui sudah sejauhmana program terlaksanan dengan baik. Ketiga, bagi peneliti berikutnya, jika ingin melaksanakan evaluasi terhadap suatu program kegiatan atau proyek dari berbagai lembaga (kementerian dan nonkementerian) disarankan untuk menggunakan model yang sama, agar memperoleh hasil yang lebih maksimal.

\section{DAFTAR PUSTAKA}

Arifin, Z. (2019). Evaluasi Program Teori dan Praktek dalam Konteks Pendidikan dan Nonpendidikan. Bandung: PT Remaja Rosdakarya.

Arikunto, S., \& Jabar, C. S. A. (2009). Evaluasi Program Pendidikan. Jakarta: PT Bumi Aksara.

Asteria, D., \& Heruman, H. (2016). Bank Sampah Sebagai Alternatif Strategi Pengelolaan Sampah Berbasis Masyarakat di Tasikmalaya (Bank Sampah (Waste Banks) as an Alternative of Community-Based Waste Management Strategy in Tasikmalaya). Jurnal Manusia Dan Lingkungan, 23(1), 136. https://doi.org/10.22146/jml.18783

Erilantu, G. S. (2016). Evaluasi Program Aksara Kewirausahaan Anyaman Bambu dalam Upaya Pemberdayaan Masyarakat di PKBM Prima Education. Jurnal Pendidikan Dan Pemberdayaan 
Masyarakat, 3(November), 165-175.

Hartono, R. (2008). Penanganan dan Pengelolaan Sampah. Jakarta: Penebar Swadaya.

Kahfi, A. (2017). Tinjauan Terhadap Pengelolaan Sampah. Jurisprudentie: Jurusan Ilmu Hukum Fakultas Syariah Dan Hukum, 4(1), 12. https://doi.org/10.24252/jurisprudentie.v4i1.3661

Kementerian Lingkungan Hidup dan Kehutanan Republik Indonesia. (2018). Sistem Informasi Pengelolaan Sampah Nasional. Retrieved November 21, 2019, from http://sipsn.menlhk.go.id/

Maulana, S., Supriyono, B., \& Hermawan, H. (2013). Evaluasi Penyediaan Layanan Kesehatan di Daerah Pemekaran dengan Metode CIPP (Studi pada Pemerintah Daerah Kabupaten Tana Tidung). WACANA, Jurnal Sosial Dan Humaniora, 16(4), 186-196.

Mulia, S., Rizka, M. A., \& Herlina. (2016). Efektivitas Program Gapoktan (Gabungan Kelompok Tani) Sebagai Upaya Pemberdayaan Masyarakat. Jurnal Transformasi, $2(2)$ $1-9$. https://doi.org/10.1017/CBO9781107415324.004

Prasetyo, A., Sakti, A. B., Gartika, D., Sukamsi, \& Arifin, Z. (2018). Bunga Rampai Inovasi Berkelanjutan: Kepemimpinan, Ekonomi, Lingkungan dan Pemerintah. Jakarta: Indocamp.

Refita, Y., Siregar, H., \& Suroso, A. I. (2017). Evaluasi Program Sarjana Membangun Desa (SMD) dan Strategi Pengembangannya (Studi Kasus Provinsi Sumatera Barat, Jawa Barat dan Nusa Tenggara Barat) Sarjana Membangun Desa (SMD) Program Evaluation and Development Strategies (Case Studies of West Sumatra,. Journal of Regional and Rural Development Planning Februari, 2017(1), 98-113.

Ridha, I. N., Sri, D., \& Ayu, F. (2018). Evaluation of Business Service Program Services ( UPJA ) to Rice Farm Productivity in Sub District Percut Sei Tuan, District Deli Serdang. (2), 180-187.

Riswan, Sunoko, H. R., \& Hadiyanto, A. (2015). Kesadaran Lingkungan. Jurnal Ilmu Lingkungan, 9(1), 31-39. Retrieved from https://ejournal.undip.ac.id/index.php/ilmulingkung an/article/view/2085

Rizani, M. D. (2019). Pengelolaan Sanitasi Permukiman Wilayah Perkotaan dengan Pendekatan Teknokratik dan Partisipatif (Teknoparti). Surabaya: Media Sahabat Cendekia.

Sahertian, P. A. (2006). Konsep Dasar dan Teknik Supervisi Pendidikan dalam Rangka Pengembangan Sumber Daya Manusia. Jakarta: Rineka Cipta.

Saputro, Y. eko, Kismartini, \& Syafrudin. (2015). Pengelolaan Sampah Berbasis Masyarakat Melalui
Bank Sampah. Indonesian Journal of Conservation, 4(1), 83-94.

Shentika, P. A. (2016). Pengelolaan Bank Sampah di Kota Probolinggo. Jurnal Ekonomi Dan Ekonomi Studi Pembangunan, 8(1), 92-100. https://doi.org/10.17977/um002v8i12016p092

Suryati, T. (2014). Bebas Sampah dari Rumah. Jakarta: Agromedia.

Triana, A. P., \& Sembiring, E. (2018). Evaluasi Kinerja dan Keberlanjutan Program Bank Sampah Sebagai Salsah Satu Pendekatan Dalam Pengelolaan Sampah Dengan Konsep 3R. Jurnal Teknik Lingkungan, 24(2), 69-78.

Wardi, I. N. (2012). Pengelolaan Sampah Berbasis Sosial Budaya: Upaya Mengatasi Masalah Lingkungan di Bali. Jurnal Bumi Lestari, 11(1), 167-177.

Wijayanti, D. R., \& Suryani, S. (2015). Waste Bank as Community-based Environmental Governance: A Lesson Learned from Surabaya. Procedia - Social and Behavioral Sciences, 184(August 2014), 171179. https://doi.org/10.1016/j.sbspro.2015.05.077

Wulandari, D., Utomo, S. H., \& Narmaditya, B. S. (2017). Waste bank: Waste management model in improving local economy. International Journal of Energy Economics and Policy, 7(3), 36-41. 